\title{
Inclusive Educational Spaces and Social Pedagogical Recognition: Interaction- and Social-Pedagogy-Inspired Analysis of Space Dynamics in Compulsory, Upper-Secondary and Post-Secondary Education
}

\author{
Goran Basic ${ }^{1, *(\mathbb{D}, \text { Galina Vasylivna Lokareva }}{ }^{2}$ and Nadiya Vasylivna Stadnichenko ${ }^{2}$ \\ 1 Department of Pedagogy and Learning, Linnaeus University, 35195 Växjö, Sweden \\ 2 Department of Performing Arts, Zaporizhzhia National University, 69600 Zaporizhzhya, Ukraine; \\ lokareva.g@gmail.com (G.V.L.); stadnichenko.nadejda@gmail.com (N.V.S.) \\ * Correspondence: goran.basic@lnu.se
}

\section{check for} updates

Citation: Basic, G.; Lokareva, G.V.; Stadnichenko, N.V. Inclusive Educational Spaces and Social Pedagogical Recognition: Interactionand Social-Pedagogy-Inspired Analysis of Space Dynamics in Compulsory, Upper-Secondary and Post-Secondary Education. Educ. Sci. 2021, 11, 754. https://doi.org/ 10.3390/educsci11110754

Academic Editor: James Albright

Received: 5 September 2021

Accepted: 2 November 2021

Published: 21 November 2021

Publisher's Note: MDPI stays neutral with regard to jurisdictional claims in published maps and institutional affiliations.

Copyright: (c) 2021 by the authors. Licensee MDPI, Basel, Switzerland. This article is an open access article distributed under the terms and conditions of the Creative Commons Attribution (CC BY) license (https:// creativecommons.org/licenses/by/ $4.0 /)$.

\begin{abstract}
The purpose of this article is to provide a new understanding of the essence of inclusive educational spaces as a pedagogical phenomenon that presents different scientific approaches to the concept of educational space, and the importance of interpersonal interactions in educational spaces, and also presents the authors' interpretations of their essence. The analytical basis is a literature review of various studies from the domains of symbolic interactionism, social constructivism, ethnomethodology, the sociology of knowledge, education, pedagogy and social pedagogy. Empirical sequences in the reviewed literature that exemplify inclusive educational spaces are derived from the organisational and practical work of compulsory and upper-secondary schools related to newly arrived students and students who use alcohol and narcotics, and from the context of the organisational and practical work of universities related to the education of future actors. The importance of recognizing the role of creative educational spaces as a leading requirement for the preparation of students for future communicative interactions in professional communication is revealed, and the structural characteristics of these spaces' content and functional load are provided. Inclusive educational spaces and professionals' inclusive approach demand that schools practically and collaboratively organise work with students in the educational space, show support for them and give them room to manoeuvre to ensure that professional actors in the school and university thrive in their practical work with students, both in relation to the expected normative right and deviant acting in the educational space and in relation to laws and governing documents that, to a certain extent, govern practical work in these educational spaces. The study contributes to the development of knowledge regarding (1) dealing with social interaction and inclusive educational spaces combining (a) the experiences of students in educational space, (b) the experiences of professional actors in educational space, and (c) the development of integration and social pedagogical recognition in educational space; (2) the significance of these social interactions and inclusive educational spaces in the creation and recreation of students' and professionals' identities; and (3) alternative social pedagogical approaches to analysing inclusive educational spaces in compulsory, upper-secondary and post-secondary education.
\end{abstract}

Keywords: interactional analysis; social pedagogical analysis; space dynamic in school; social pedagogical development; dramatisation; teacher; educator; pupil; success; obstacles; educational cooperation; social pedagogical space

\section{Introduction}

The educational space is a part of the sociocultural life of society. It determines the level of everyday, educational, professional environments of the person at the macro, meso and micro levels in relation to the individual formative, educational, developmental and 
other functions and, influencing consciousness, determines the direction of activity within the educational system. From the standpoint of social pedagogy, the concept of "condition" is a circumstance that ensures the successful solution of the tasks of the educational process, thereby creating an atmosphere of educational cooperation between actors in inclusive educational spaces [1-10].

Social and pedagogical activities in educational space play a crucial role in the development of children and students in both a social and a pedagogical sense. School dropouts or failures in compulsory, upper-secondary and post-secondary schools are portrayed as being more likely to abuse alcohol and narcotics, as well as being more prone to criminality, mental illness, and to experiencing difficulties in establishing themselves in the labour market [11-25]. Conversely, good attendance at school and university and good grades are portrayed as being linked to reduced risk of social and pedagogical problems that can affect teenagers and young adults [11-14,19-27].

Educational spaces in schools and university can contribute to the stability of a young person's life; indeed, education is a central resource for promoting independ-ence among young people, as well as for establishing oneself in the labour market and participating in society at large [9,28-30]. Fothergill and Ensminger [31], Tsymbalaru [13], Kryvykh [14], Trenz et al. [32] and Warne et al. [23] highlight the importance of children and students having a good connection to schools and universities, and of positive relationships with teachers and other professional actors in the educational space, as well as good grades, all of which provide a protective dimension against the risky consumption of alcohol and the use of narcotics in adulthood. In previous re-search, the educational space in school and university has been dramatised as a space that can be safe-where recognition can be bestowed in a social and pedagogical sense-which in turn can strengthen the self-esteem of the student.

Studying both the experience of teachers and students, prominent figures of the inclusive educational spaces in school and university, and generalisation of the authors' own social pedagogical analytical observations of the authors of this article made it possible to determine the leading condition for the preparation of the future actor for communicative interaction in interprofessional communication and communication with students-in the sense of creation and recreation of inclusive educational spaces $[9,28-30,33-36]$.

Previous research has drawn attention to the importance of interpersonal cooperation for successful schooling and success in the practical work of education. These studies have emphasised the importance of successful cooperation between various professional occupational groups in educational spaces in order to achieve success for the students in these spaces. The authors stress the importance of cooperation between various types of professional actors in educational spaces, as well as between different types of professional actors and studentswith the common goal of working together to help students achieve success in school and university spaces in a social, pedagogical and educational sense [9,28-30].

Knowledge about inclusive educational spaces, social pedagogical recognition, and space dynamics in schools and universities is limited. We know too little about the extent to which various categories of professional actors and students really cooperate in educational spaces regarding students, or about the ways in which the identifications of the actors play a role in ongoing social pedagogical processes in educational spaces in schools and universities. Knowledge of whether cultural and social differences contribute to common starting points in the work - and thus to success and/or obstacles in the work of schooling students in inclusive educational spaces - needs to be developed, and on this point we hope to provide a contribution within the framework of this analysis.

That article is part of the research project "School success for newly arrived students: possibilities, obstacles, identities and collaboration" and "School as a protection factor. An analysis of achievements, obstacles, collaboration, and identities in senior high school work with students who use alcohol and narcotics", which was conducted at Linnaeus, Lund and Kristianstad universities in Sweden, Kochi University in Japan and Zaporizhzhia National University in Ukraine $[37,38]$. The aim of this article is to provide a new under- 
standing of the essence of inclusive educational spaces as a pedagogical phenomenon that presents different scientific approaches to the concept of educational space, as well as an understanding of the importance of interpersonal interactions in educational spaces. The research questions addressed in the study is this: How are inclusive educational spaces, social pedagogical recognition, and space dynamics in school and university represented in relation to previous research on the phenomenon?

\section{Theoretical Starting Points}

Symbolic interactionism, social constructivism, and ethnomethodology are some of the theoretical scientific starting points used in the analysis of the inclusive educational spaces and social pedagogical recognition in compulsory, upper-secondary and post-secondary education [1-10,39-44]. The use of these scientific theoretical starting points will lead to a higher level of analysis of the inclusive educational spaces and social pedagogical recognition and will facilitate understanding on two fronts. First is the educational reality in various educational spaces in which the individual acts or is expected to act in myriad interpersonal interactions that characterise these spaces. Second is the significance of interactions for the creation and re-creation of oral representations, verbal portrayals, and represented images that are constructed and reconstructed in interpersonal interactions in these different educational spaces [39-52].

Educational reality is not a stable and immutable social phenomenon; rather, it is changeable and characterised by constant interactive processes, changes in interpersonal encounters, and dynamic activities tied to the various situations in the spaces in which these interactions occur [39-44,47,49-51,53]. The words Space (or Context-with Collins' conceptual apparatus or Region-with Goffman's conceptual apparatus) are used to connote the delimited field where a series of educational interactive activities (educational situations - educational interactive rituals) are played out and can be delimited by the actors' observational and hearing abilities. Empirical examples from compulsory, uppersecondary and post-secondary education of these interactive flows in the myriad interpersonal interactions that occur in an educational space include the interactive actions of actors in a particular situation, the narrative representations of a particular situation by actors, and the productions and reproductions of important educational objects such as language, text, documents, laws, news, images, and videos [39-44,48,53-57].

In the educational interactive sense, the delimited field of "educational space" can be analysed as consisting of three subspace regions. The front subspace refers to the subregion where the performance of the actors themselves (as action, reproduction, and/or production of educational objects) takes place. The back subspace (behind the scenes) is a subregion that actors in the surroundings (the audience) cannot access. In this subspace, those who are acting in education, representing, and/or producing can shape their future performances and reflect on their past performances, prepare, or relax [39-44,47,49-51,53]. Some subspaces can be both a back space and a front space. For example, compulsory and upper-secondary schools, universities, classrooms, and various offices (e.g., of the head teacher, school nurse, counsellor) can educationally act as one or the other. The designation of front space or back space depends on the actor's particular performance and the function of the space at the time.

The third region is outside/off-space (the outsider/exclusion region). This subspace represents everything that does not belong to the front or back educational space. The actor who educationally acts, reproduces, and/or produces on the outside is an outside actor. In their relationships with actors established in the front or back space, the educational performance of outsiders risks creating and re-creating conflicts in the interaction. An outside actor who steps onto the front space or back space by educationally acting, reproducing, and/or producing important educational objects in these subspaces creates temporary confusion by disrupting the educational order and forcing a redefinition of the situation in the educational space [39-44,47,49-51,53]. 
The space reasoning of theorists on this subject made us curious about what might be occurring in various represented situations in the school and university educational space. With this question as a starting point, we found that the informants in the reviewed literature, when constructing and reconstructing their professional and personal identities, typify actors from both the front and back stage subspaces, as well as from the outside (offspace). Just as the classrooms in compulsory, upper-secondary schools and universities can be both a front space and a back space, the typical actor in space can be both a professional actor in these subspaces and an actor outside the organisation, such as a student.

When actors in educational space interact, they try to make educational reality comprehensible, and in doing so, they construct and reconstruct their identities. Typifications thus fulfill an important function in educational interactive creation and re-creation. The division into categories and typification of individuals, professions, and events-their identification through categorisation-is necessary for navigating the myriad everyday educational interactions. Typification is not a static process; rather, it changes from one educational interactive flow (educational situation) and space to the next. The educational actions, representations, and productions of one actor constitute a motive for and a response to the educational actions, representations, and productions of the other. In this process, the affiliations and self-esteem of the involved actors, their creation and re-creation of various social and pedagogical identities, and their recognition in these identities take shape and are modified and confirmed [39-53]. In light of these theoretical perspectives, the practical educational actions of both students and professionals in compulsory, uppersecondary and post-secondary education space, as well as analysis of these actions, can be regarded as meaning-making activities. These educational activities can contribute to the development of knowledge that can promote the involvement and success of both students and professionals in situations that characterise these educational spaces.

An important starting point in analyses rooted in the above scientific theory is that actors in all educational spaces are grouped and typified in relation to their interactive positioning in a given context in which certain actors/types have the advantage in relation to the others. Thus, certain actors/types in the space will have greater authority and higher social status than others. As a result, they have an interactive advantage in defining and re-defining how educational space, groups, types, and actors should educationally act and be represented, produced, and reproduced [39-53]. In its most dramatic form, this advantage may lead to the oppression of individuals with lower status in educational space.

\section{Methodological Starting Points}

This literature review is based on a qualitative method [54,57]. Empirical studies and empirical sequences in these studies that are reanalyzed in the present analysis are of a secondary nature $[29,30,58]$. Selection of the relevant empirical studies and the first analysis of the empirical data in these studies were performed in connection with previous analyses [11-14,19-22,24,25,29,30,59-69], [70] pp. 8-12, [71] pp. 10-17. Reanalysis in the present literature study is carried out on the basis of the study's purpose and research question by reanalyzing the selected studies using (1) interactionist, constructionist and ethnomethodological scientific theoretical starting points, (2) the general perspective from social pedagogical work and research particularly related to the concepts of "inclusive educational spaces" and "social pedagogical recognition".

In the spirit of interactionism, constructivism, and the ethnomethodological approach, the literature study analyses how students and professional actors themselves (in the analyzed literature) use identity-related and cultural resources (e.g., narratives, metaphors, vocabulary, roles, educational status symbols) in the day-to-day interaction in the educational space, such as when they talk about advantages in the educational interaction, describe working conditions, formulate criticism, and process their experiences. The fact that certain actors/types command an advantage in relation to others is important in the analysis of the present study in two ways: first, in the representation of relationships 
between students and professional actors (here, in the literature regarding inclusive educational spaces in compulsory, upper-secondary and post-secondary education), and second, in the representation of the relationships of these students and professionals to the space dynamic in the organisational and practical work of compulsory and upper-secondary schools with newly arrived students and students who use alcohol and narcotics, and in the representation of the relationships of students and professionals to the space dynamic in the organisational and practical work of universities related to the education of future play-actors. For this study, therefore, the representation of working with students is analysed less in terms of static typifications and more in terms of situational and space-bound (institutionally and materially positioned) interactions described in the analysed literature.

\section{Organisational and Practical Work with Newly Arrived Students}

Fuller [19] studied how a headmaster's exercise of power, identity, and language is represented, constructed, and reconstructed based on interactions with government officials, politicians, teachers and parents of students. Fuller shows that power interactions and languages in educational space varied widely in different meetings and that the ethnic identity of the headmaster took on different meanings depending on the other participants. Awareness of one's own professional role in the school was dramatized by Fuller as an important tool for shedding light on how the representation was experienced by the students whom the teachers and other staff in the school were supposed to teach. Fuller asserts that the interactive importance and positioning of power by different actors in the school educational space (headmaster, teacher, student, parent) must be analysed in relation to power interactions, identity, and language, and that this analysis can contribute to raising awareness of how the educational space is designed both organizationally and practically $[19,24],[70]$ pp. 8-12.

Björk et al. [29] highlight how newly arrived students portray teachers in school educational space as both uninterested in teaching students and as disrespected by newly arrived students. The analysis also presents a portrait of an active and strategic teacher who is an important player in the practical work with the students on an individual basis. Such a teacher educationally acts as an interactive support to overcome obstacles that may otherwise hamper collaboration between teachers and students. Popov and Sturesson [64] present the gap between the former learning culture of newly arrived students and that of their new society, and they show the importance of actively helping these students bridge the differences. Both Björk et al. [29] and Popov and Sturesson [64] stress the importance of not viewing newly arrived students as a homogeneous group in educational space. Both studies emphasise the value of getting to know each student as an individual beyond their categorisation to more easily see and use their individual circumstances, experiences, and needs [24], [70] pp. 8-12.

Torbjørnsen Hilt [66] highlights that newly arrived students need to be supported in understanding what is expected and required of them in a new social and educational space. Torbjørnsen Hilt draws attention to the fact that the careers of newly arrived students are at risk if they do not receive the support in educational space they need as new arrivals. Among other things, the study's analysis casts light on teachers' belief that many newly arrived students do not know what is expected of them as students in the educational space. The teachers believe that the expectation of more independent learning contrasts with the students' previous school experiences with authoritarian and active teachers [24], [70] pp. 8-12.

Eek-Karlsson et al. [68] have analysed the construction and reconstruction of the actors' gender, ethnicity, and sexual orientation in educational school space. These authors argue that there is variation in a school's different ways of working to combat discriminationeven as at the same time this work usually contributes to the strengthening of actions that are categorised as normatively right (morally right) and deviant (morally wrong). EekKarlsson et al. [68] highlight the point that classroom educational space (teaching) tends to focus on the other rather than broadening teaching so that it becomes norm breaking and 
creates space for the increased inclusion of all participating students (including "the other"). The authors stress that schools have different starting points in their anti-discrimination work regarding who or which categories of students are considered to be problems or deviant. They also stress that through practical social pedagogical work, schools risk reinforcing, producing, and reproducing stereotypes that otherwise and generally characterise school educational space [24], [70] pp. 8-12.

Berggren et al. [69] portray the importance of paying particular attention to frustration among newly arrived students at not understanding the content communicated in the majority language during their lessons. The authors stress the importance of preserving and strengthening a student's different identities while new language and knowledge are introduced into the student's life. To achieve success in working with newly arrived students, schools must ensure an inclusive pedagogical/educational space wherein a student's past and new identities are made visible, while these different identities must also be incorporated into the current interactions between teachers and students in the educational school space [1-10]. To achieve this aim in working with newly arrived students, it seems important to highlight the role of the mother tongue teacher and study supervisor in relation to other categories of teachers and students. Wedin's study [67] indicates that in interactions in the educational school space, mother tongue teachers and study supervisors are often used as translators or language reviewers-which is not consistent with the task they have in the educational space as language teachers. Berggren et al. [69] argue that mother tongue teachers and study supervisors must be invited to take part in joint discussions and possible collaborative projects aimed at promoting the success of newly arrived students in the educational school space [24], [70] pp. 8-12.

\section{Organisational and Practical Work with Students Who Use Alcohol and Narcotics}

Onrust et al. [65] draw attention to the various stages of social pedagogical development (in the developmental social psychological sense) when designing alcohol and narcotics prevention efforts in educational school space. These researchers argue that prevention efforts in educational space should be planned based on the mental and cognitive needs and capacities of children or young people. Their study constructs and reconstructs an understanding of the importance of starting prevention work in primary educational space because children at this age are assumed to be impressionable and quick to learn what constitutes normatively right and wrong behaviour. Their study also dramatises the ability of children in primary educational space and intermediate level compulsory school to highly value the opinions of parents and teachers regarding normatively right behaviour in relation to alcohol and narcotics. This attitude enables the expert's (teacher's) professional work to influence the child in refraining from using alcohol and narcotics [25], [71] pp. 10-17.

The authors in Onrust et al. [65] further point out that alcohol and narcotics use is rare in primary and intermediate level compulsory school. They therefore highlight the relevance of teaching children in educational space about the risks of alcohol and narcotics during that social pedagogical developmental period. The role of professional actors during this time is to encourage children to practice skills for more easily handling the challenges of later developmental phases based on the risks they have learned to associate with alcohol and narcotics. The point of that study is that prevention efforts in educational space and cooperation among various professional actors, students, and parents should not be delayed until a time when students are coming into contact with alcohol and narcotics. Instead, these authors argue, prevention work and cooperation should be designed and implemented considerably earlier in educational space. They emphasise that during senior level compulsory school and the start of upper-secondary school, a social pedagogical separation begins. Young people free themselves from their families, become more independent, often reject the normative values of their parents and teachers, and value the normative values of their friends over those of parents and teachers. During this phase of social pedagogical development, students in educational 
space are dramatised as being more aware of the benefits of using alcohol and narcotics while also caring less about the inherent risks. Because students in this social pedagogical developmental phase are constructed as being resistant/unreceptive to the parent and teacher perspective in relation to values and norms of alcohol and narcotics use, students are also characterised as difficult to influence and change when it comes to this use [25], [71] pp. 10-17.

Onrust et al. [65] present creation and re-creation of several explicit and implicit portrayals of protection and risk dimensions in educational space in relation to the category "students who use alcohol and narcotics". The protection dimensions are as follows: prevention efforts aimed at school-age children in educational space, carried out in cooperation among different professional actors, children, and parents; cooperation and prevention efforts already implemented during primary school; parent and teacher actions based on perceptions of normatively right behaviour in relation to the use of alcohol and narcotics (not using alcohol and narcotics); and actions of friends based on perceptions of normatively right behaviour in relation to the use of alcohol and narcotics (not using alcohol and narcotics). The risk dimensions portrayed are as follows: common obstacles to cooperation among various professional actors, student, and parents; the age of the young person because older age makes it more difficult to influence students to follow the "right" norms; student's rejection of perceptions that adults and teachers have of normatively right behaviour in relation to the use of alcohol and narcotics (i.e., students think it is OK to use alcohol and narcotics and reject these "right" norms); and the behaviour of students in relation to friends who have rejected the "right" norms and use alcohol and narcotics [25], [71] pp. 10-17.

Sznitman et al. [63] investigated links between educational school space with environments considered "good and safe" and a reduction in the use of drugs in the form of tobacco, alcohol, and cannabis. Their study paints a picture of students who are in a good and safe educational space and thus using drugs less than students in schools with an unfavourable educational space. These authors stress that merely conducting various drug tests in educational space does not reduce the use of drugs or function as a deterrent to students. Their study dramatises the importance of analysing and evaluating the educational space as practical and organisational work before implementing the preventive measure of testing students for drugs. The authors implicitly argue that targeted efforts to improve the educational space have a greater effect on reducing drug use than methods such as testing students. In addition, they emphasise that targeted programmes, policies, and preventive drug measures in educational space directed by professional actors do not appear to reduce drug use among students. Instead, Sznitman et al. [63] stress the importance of working in educational school space to create, re-create, and learn a professional approach that encourages the student to participate in prevention efforts. They also emphasise professional social pedagogical competence development that allows professional actors to interact with students in a way that accounts for the individual knowledge and skills of each student. With this emphasis, the study implicitly underscores the importance of cooperation in educational school space among students, parents, and professional actors [25], [71] pp. 10-17.

In this way, Sznitman et al. [63] present the risk dimension inherent in the practical actions of professionals in the educational school space (in the form of targeted prevention programmes, drug testing, policies, and preventive drug measures). These actions in educational space are presented as ineffective. Not only do they not seem to reduce student's drug use, but also they can contribute to the stigmatisation of students and the strengthening of student's rejection of perceptions of normatively right behaviour in relation to the use of alcohol and narcotics (i.e., not using alcohol and narcotics). Koning et al. [62] draw attention to the importance of cooperation among professional actors, parents, and (implicitly) students in educational space with the aim of involving students and parents in prevention efforts to combat student drug use. The study suggests that prevention efforts yield better results if parents are involved in the work in educational space. For example, 
parents are portrayed as being able to influence student's initial exposure to alcohol use. This portrayal reinforces the importance of the production and reproduction of targeted prevention programmes by professional actors in educational space [25], [71] pp. 10-17.

In keeping with Sznitman et al. [63] and Onrust et al. [65], Koning et al. [62] also highlight cooperation among professional actors, parents, and students as an important protection dimension in relation to the category ("students who use alcohol and narcotics"). In the inclusive educational school space, parents and students are not professional actors and can thus be perceived as outside the educational space; actors whose performance can create and re-create conflicts [1-10,29,30,39-44,47,49-51,53].

\section{Organisational and Practical Work with Future Actors}

Kryvykh [14] examines the concept of educational space based on the territorial principle (world educational space, state, regional, educational space of educational institution), based on the spheres of social pedagogical activity, where the purposeful formation of personality is carried out, which leads to an increase in the social pedagogical, intellectual and economic potential of society.

Considering the educational space in relation to the theory and practice of higher education, Pogrebova [60]) defines it as a condition of social pedagogical activity of the teacher. As a social pedagogical reality, the educational space is defined by Leonova [61], in which the connection of a person with the surrounding world is manifested throughout the educational activity. Chumychova and Redko [59] characterise the educational space as a set of interacting environments, social pedagogical and educational situations that nourish the process of activating the creative initiative of the individual, revealing its potential capabilities.

Tsymbalaru [13] characterises the concept of "educational space" as a reflection of the system of social pedagogical connections in the field of education, a structured system of social pedagogical dimensions aimed at the development and formation of personality in a specially organised social pedagogical and educational environment. The author examines the educational space as a place where the creative potential of all participants in the social pedagogical and educational process, the nature of which depends on the territory, location, and cultural roots are ensured.

In order to successfully include the students in the learning process in educational space, Bekker and Zhuravchik [12] propose the creation of an educational space of a higher education institution based on the following principles: (1) fundamentalisation (mastering a wide range of professional knowledge); (2) practical orientation of vocational education (mastering practical skills required for professional activity); (3) unity of education, life and professional activity (combined within the educational space of professional, social and educational activity); (4) personification of educational space (creation of micro-conditions and micro-factors for realisation of creative abilities and possibilities).

Generalising the views of scientists, we clarified the working concept of "educational space" in post-secondary education as a social pedagogical phenomenon of interaction of the students with the other students, teachers (professional creative educational activity) and surrounding media. The educational space is part of the social pedagogical environment in which the student, professional and social pedagogical formation of the student takes place. Accordingly, it is saturated with various types of information in educational space: cognitive, artistic, aesthetic, social pedagogical, educational, multifaceted professional, etc. It allows the creative abilities of the student to be revealed and stimulates and ensures the participation of the student in various forms of creative educational activity. According to the specified functionality, educational space can be defined as informative-creative social pedagogical space [1-10,12-14,59,60].

Creating an informative-creative educational space in a higher education is a prerequisite both for the professional training of the future play-actors and for preparing them for professional communication in their future career. The key points in the creation of an informative-creative educational space for future play-actors were (a) principles 
of creating an educational space [12] and (b) a structured system of social pedagogical dimensions [13]. The principles proposed, according to which the educational space of the higher education should be created and re-created, became the normative and regulatory provisions for revealing the content of the conditions of preparation of the future play-actor for professional communication in the future career $[12,13]$. The content of this condition consists of two essential social pedagogical aspects: information and creativity.

Lokareva [11] portrays the importance of paying particular attention to the process of professional communication, when the play-actor broadcasts to the audience both artistic and aesthetic social pedagogical information about the theatre artwork. Therefore, in the professional training, it is important to saturate the educational space with all possible sources of artistic and aesthetic information because the future specialist during training must master a wide range of ways of implementing it [1-10].

The social pedagogical informational component of the educational space is full of artistic and aesthetic information about works of different kinds of art. The theatrical art is inherently synthetic - it is a combination of all kinds of arts; therefore, the future playactor, through appropriately organised educational space, learns to understand and master the means of perception and means of broadcasting of all kinds of artistic and aesthetic information of each type of art: social pedagogical, cognitive, artistic, aesthetic, intellectual, emotional, psychological, moral-ethical, individual-authorial, pragmatic [1-11,20-22]. The main property of the social pedagogical type of information is a change of thesaurus, a replenishment of the stock of knowledge through perception of works of art. The type of artistic social pedagogical information contains an idea, aesthetic concept, artistic images and means of their translation. The aesthetic social pedagogical information is peculiar only to works of art; it is interdependent on artistic information and its means of broadcasting [1-11,20-22].

The intellectual social pedagogical information determines the level of awareness of the world and its diversity, complexity and contradictions, and it encourages the evaluation of social pedagogy and moral and aesthetic phenomena. The individual-authorial information depends on (1) the action of the artist in social pedagogical meaning, on her/his ways of thinking, creation of action, and perception of reality; (2) moral and ethical information reflects the norms of social pedagogical relations, customs, traditions, moral and ethical conditions of human existence, related to specific historical, political, economic, cultural specifics of the era, country, nationality; (3) social pedagogical information reveals the inner state of the character; (4) it reveals cause and effect connections of interpersonal relationships, conflicts, social pedagogical atmosphere; (5) social pedagogical information is a source of emotional impact of a work of art on the recipient, her/his social pedagogical levels and bio currents; (6) pragmatic social pedagogical information contains a message about its value and usefulness to the subject of perception. Students must master the artistic and aesthetic system of information about each type of art, specifically through characteristic channels of perception: (a) audio-imaginative information, the source of which are all kinds of music art; (b) visual-imaginative information contained in works of fine art; (c) audio-visual-imaginative information carried by the theatre arts, cinema, literature, etc. [1-11,20-22]. The social pedagogical informational component of the educational space should satisfy the students' desire for active and conscious learning of the theoretical material of the academic disciplines, and for interaction in the search for ways of cooperative solving of creative problems.

Lokareva [11,20], Lokareva and Gualotunya [21] and Lokareva and Stadnichenko [22] argue that, before achieving free expression of his own creativity, the student, the future play-actor, should be freed from social pedagogical barriers through direct immersion into creative educational space. The creative aspect of the educational space provides a variety of opportunities for creative realisation of the future play-actor and the desire to test in practice the rightfulness of opposite creative decisions. (Creativity means creation, from Latin, Creatio is creation. In philosophical interpretation, creativity is the ability of the individual to create spiritual and intellectual values, objects of material culture.) 
Creativity is a characteristic of a gifted personality with developed social pedagogical imagination, fantasy, desire for active expression, ability to think in original, nonstandard ways. Creativity is manifested in the ability of the individual to find nonstandard ways to solve problems, in the tendency for empathy, in the desire for social pedagogical selfaffirmation, and in the independence of creative thinking. In social pedagogical research, several aspects of creativity stand out: creative process, creative product, creative actor (in interactional and social pedagogical meaning), creative environment or a creative educational space [1-11,20-22].

\section{Model of Social Pedagogical Informative-Creative Educational Space}

A model of social pedagogical informative-creative educational space has been developed (Figure 1), the structure of the which consists of two levels (external and internal), which simultaneously influence the preparation of the future play-actor for social pedagogical professional communication and which are schematically presented in the form of circles that surround the student and the teacher [22] p. 145.

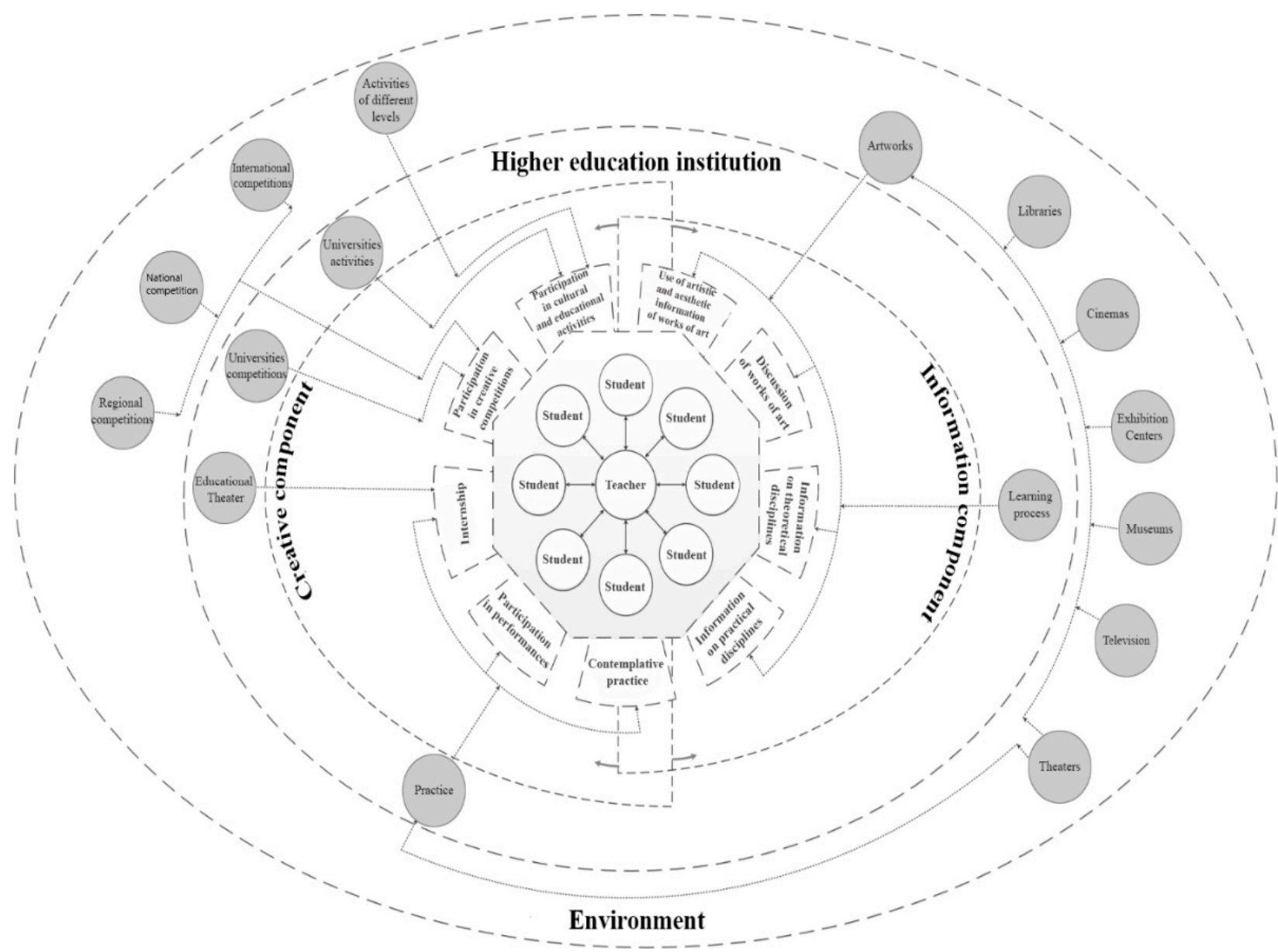

Figure 1. Model of social pedagogical informative-creative educational space.

Both the external and internal levels of the educational space contain social pedagogical informational and creative components, the characteristics of which have been presented above. Being organised in this way, the educational space in social pedagogical meaning contributes to the personal formation of the individual, the expansion of the professional thesaurus, the acquisition of a wide range of knowledge from many fields of human activity and their constant updating, continuous work on improving the skills of professional communication, and the formation of a high level of self-awareness in relation to one's own creativity. 
The social pedagogical informational side of the external level of the educational space, whose bearers of culture are libraries, cinemas, exhibition halls, city theatres, museums, and television, is saturated with artistic and aesthetic information on works of art. The future play-actor, through appropriately organised immersion in this educational space, learns to understand and master the means of perception and the means of broadcasting the artistic and aesthetic social pedagogical information of each type of art.

This component contributes to the social pedagogical development of the general culture. The aesthetic taste of the student changes his or her thesaurus and forms the skills of perception of artistic and aesthetic social pedagogical information of different types of art (visual, theatre, music, cinema) through the lens of theatre. Acquaintance with the works of classical and contemporary dramaturgy - both art critic and required educational literature within the social pedagogical information-creative educational space-ends with an active discussion in the audience and the exchange of obtained impressions.

The social pedagogical creative aspect of the external educational space provides a variety of opportunities for creative realisation of the future play-actor through participation in events of different levels (international, regional creative competitions and festivals, etc.). The external structural level of the social pedagogical informative-creative educational space is characterised by the student's activity in the search for new opportunities for professional communication outside the university classrooms because, having mastered the initial skills of professional communication, he or she seeks to realise them in more complex forms, in a variety of different projects, professional competitions, or festivals.

At the inner structural level, an exchange of information happens between students and teachers throughout the educational process. A professor being a guide to the plane of the social pedagogical informative-creative educational space, carrying out the educational process, conducts individual work with each member of the study group, creates an atmosphere of understanding and trust, and promotes the formation of personal and professional qualities.

The social pedagogical creative component of the internal level of the social pedagogical informative-creative educational space is the organisation of students' educational and creative activities within the classroom and outside the classroom walls of the educational institution: industrial and social pedagogical practice, participation in organisation of holidays for children with disabilities or in orphanages, cultural and educational activities, creative meetings with artists, participation in programmes on state television, creation of diploma performances and playing on the stage of educational theatre, etc.

The basis of the relationship between the teacher of professional disciplines and the future play-actor is a passion for the art of theatre, which combines social pedagogical activities and creative interaction in all the various aspects of the social pedagogical informative-creative and educational space. Creating a social pedagogical informativecreative educational space and immersing a student into it provides (1) cognitive activity of students; (2) motivation to gain professional knowledge, formation of skills; (3) active interaction of the teacher and the student during the educational activity; (4) social pedagogical creative approach to the modeling of relationships in communicative systems: "teacher-student", "student-student", "student-collective", "student-teacher"; (5) various displays of kindness, understanding and tolerance in the relations of the participants in the educational process; (6) stimulating the collective support of each student for social pedagogical creative self-realisation; (7) positive perception of any creative position of the student, active cooperation, creativity, partnerships with students; (8) stimulating the demonstration of a high level of culture in communication between participants in the educational space (educational process); (9) organisation of collective creative actions in the educational space (educational process); (10) establishing personal contacts with each and every student; (11) formation of friendly, tolerant relationships between the teachers and the members of students collective. 


\section{Findings and Discussion}

The paper aims to provide a new understanding of the essence of inclusive educational spaces as a pedagogical phenomenon that presents different scientific approaches to the concept of educational space, as well as an understanding of the importance of interpersonal interactions in educational spaces. To do so, a literature review of several studies from different domains is provided, and empirical sequences from the context of the organizational and practical work of compulsory and upper-secondary schools and universities are presented. On the basis of these premises, a model of social pedagogical informative-creative educational space has been created.

The theoretical contribution of the study is the development of knowledge regarding social interactions and educational space in compulsory, upper-secondary, and postsecondary education. The study shows how a good connection to the school and university space and successful cooperation between different types of professionals and students are two important dimensions of inclusive educational spaces that can reduce the risk of social and pedagogical problems for students.

The inclusive educational spaces in compulsory, upper-secondary and post-secondary education can be analysed as a region where social pedagogical recognition can be given, which can strengthen self-esteem for both teachers and students as well as their sense of belonging, involvement, and inclusion [1-10]. The school and university educationalspace dynamic of teachers and students is constructed and reconstructed through mutual recognition. The self-realisation of students and teachers is created and re-created through participation in educational space by means of successful interactions that contribute to the production and reproduction of knowledge, desirable abilities, and experiences. This is possible only if teachers and students are recognised in the current educational dynamic, in close relationships, and in interaction with other actors in the educational space. The quest for recognition in the school and university educational space is sometimes based on the exclusion of the other. Discrimination, abuse, and bullying can negatively affect self-esteem in both teachers and students. Furthermore, exclusion from the educational space risks destroying the actors' self-esteem. This risk applies in particular to the exclusion of students who have a lower status in the educational space than teachers $[9,19,24,25,29,45,52,68]$.

Teachers are among the most important actors in the compulsory, upper-secondary and post-secondary inclusive educational spaces. Teachers can contribute to achieving social pedagogical recognition, school success, and the successful integration of students into educational space. Previous research shows that social pedagogical recognition, school success, and successful integration are more closely connected to the active action of individual teachers in the school and university educational space who "show up," engage, and help than to the school and university as an organisation $[9,19,24,25,29,30,68]$.

Trends from professional practice that permeate some of the above-mentioned research include emphasis on the student's personal responsibility for interactive choices and achievements occurring in educational space. In the interactive space dynamic, "problems" that students have with the new language, integration, health, alcohol, drugs are framed as personal and individually located. This framing can negatively affect their self-esteem, self-image, sense of belonging, identities, and patterns of action, contributing to a lack of social pedagogical recognition in the educational space. Previous research has indicated a tendency in which different categories of teachers risk individualising students' problems in terms of the background and behaviour of the students (and sometimes parents, in regard to compulsory and upper-secondary school). This tendency in turn ignores the analysis of other important analytical aspects that can, e.g., explain dimensions in schools and universities' organisation of practical educational work with students. When problems are individualised by simply focusing on the students' background as a starting point, the process becomes discriminatory and hinders the students' school and university success.

The predominant everyday declarations about the category "students with problems" seem to focus on psychiatric or medical needs, whereas competing explanations seem relatively toned down. The latter includes (1) established inequalities in society and 
educational space, (2) material and institutional difficulties in societal and educational space, (3) bureaucratic hurdles in educational space and in the rest of society, (4) ethnic monitoring and social control in society and educational space, (5) the humiliated identities of the actors in a societal and educational space, (6) victimisation in relation to the majority in the educational space, (7) demeaning ethnic categorisations in society and educational space, and (8) discrimination in the educational space and an overall societal context $[19,24,25,29,30,72,73]$. Additional competing explanations that appear to be relatively muted in relation to the diagnostic aspect are the interpretations of students of their experiences, such as "I have unique experience that I can benefit from in the future"; "I have learned to cope with difficult things"; and "I am strong now." There are many interactive points of entry to the social pedagogical recognition of both students and teachers in the educational space $[9,19,24,25,28,29]$, and no single recipe always or most commonly applies. The social pedagogical recognition in educational space is produced and reproduced through a series of interactions in which actors first are involved in educational identifications in different ways and secondly make use of/or suffer from their own identification streams or those of others in the myriad interactions in educational space, at home, and in society at large.

The social pedagogical creation, and accordingly availability of social pedagogical informative-creative educational space, is a leading organisational, pedagogical and educational condition of preparation of the students for future professional communication. It assures the formation of the future professional's readiness for communicative interaction in professional social pedagogical communication. Immersion of students in a social pedagogical informative-creative educational space promotes trusting relationships of students in the team, the absence of violations of ethical norms of interpersonal interaction, the creation of a community of like-minded people, the liberation of their own creative potential, the realisation of inner needs, and the desire for steady self-improvement and self-development. It also allows students to widely implement different types of communication in the process of mastering the basics of professional social pedagogical communication. It promotes the social pedagogical creative nature of the student and predicts his/her creative perspectives.

The social pedagogical activity within the framework of social pedagogical informative-creative educational space is aimed at the formation of students' personal and professional qualities, motivation to study, and their mastery of subject content related to their future profession. Involvement and inclusion of the student in the educational activity allows manifestations on his/her part of the initiative, and the free exchange of social pedagogical creative ideas, thoughts, critical remarks, i.e., stimulating the formation of readiness for communicative social pedagogical interaction in professional communication. The teacher of professional disciplines, carrying out the organisation of social pedagogical informative-creative educational space, should solve educational tasks in both social pedagogical and creative terms.

Further studies are needed regarding (1) the relationship of professional social pedagogical communication with other types of professional activity of the actor and mechanisms of interaction of subjects of professional communication; (2) the practical suggestion provided by the model of social pedagogical informative-creative educational space; and (3) the questions of (a) how different groups of professionals interact to improve students' experience and (b) which professional categories are needed in inclusive educational spaces. In addition, as a consequence of the analysis in the present study, further research is requested related to (1) identity creation and the re-creation of teacher and pupil/student identities that act in social pedagogical space during the social pedagogical activities in compulsory, upper-secondary and post-secondary education; (2) the importance of social pedagogical recognition of teacher and pupil/student identities for inclusion in a community of education and for overall integration in a society; (3) production and reproduction of power relations, conflicts, resistance and consensus between teachers and pupils/students during these social pedagogical activities; (4) the importance of social pedagogical control 
and social pedagogical monitoring for teachers' and pupils'/students' actions in school and university-actions that seem directly and indirectly influenced by the written and unwritten rules within the framework of social pedagogical informative-creative educational space, norms, values, curricula, regulations, schedules, tests and other different practical teaching situations.

Author Contributions: Conceptualization, G.B; methodology, G.B; software, G.B., G.V.L. and N.V.S.; validation, G.B., G.V.L. and N.V.S.; formal analysis, G.B., G.V.L. and N.V.S.; investigation, G.B., G.V.L. and N.V.S.; resources, G.B; data curation, G.B., G.V.L. and N.V.S.; writing-original draft preparation, G.B., G.V.L. and N.V.S.; writing—review and editing, G.B.; visualization, G.B.; supervision, G.B.; project administration, G.B.; funding acquisition, G.B. All authors have read and agreed to the published version of the manuscript.

Funding: This research received no external funding.

Institutional Review Board Statement: The study was conducted according to the guidelines of the Declaration of Helsinki, and approved by the Regional Ethical Review in Sweden 2018 (in Linköping; Board Reg. No. 2018/81-31 and Reg. No. 2018/82-31).

Informed Consent Statement: Not applicable.

Data Availability Statement: Not applicable.

Conflicts of Interest: The authors declare no conflict of interest.

\section{References}

1. Eriksson, L.; Winman, T. (Eds.) Learning to Fly: Social Pedagogy in a Contemporary Society; Daidalos: Gothenburg, Belgium, 2020.

2. Hämäläinen, J. Social pedagogical eyes in the midst of diverse understandings, conceptualisations and activities. Int. J. Soc. Pedagog. 2012, 1, 3-16. [CrossRef]

3. Úcar, X. Exploring different perspectives of social pedagogy: Towards a complex and integrated approach. Educ. Policy Anal. Arch. 2013, 21, 1-15. [CrossRef]

4. Eriksson, L. The understandings of social pedagogy from northern European perspectives. J. Soc. Work. 2014, 14, 165-182. [CrossRef]

5. Kornbeck, J.; Úcar, X. (Eds.) Latin American Social Pedagogy: Relaying Concepts, Values and Methods between Europe and the Americas? Europäischer Hochschulverlag: Bremen, Germany, 2015.

6. Hämäläinen, J.; Eriksson, L. Social pedagogy in Finland and Sweden: A comparative analysis. Pedagog. Soc. Rev. Interuniv. 2016, 27,71-93. [CrossRef]

7. Janer, A.; Úcar, X. An international comparison: Social pedagogy training. J. Soc. Work. 2019, 19, 253-275. [CrossRef]

8. Janer, A.H.; Úcar, X. Social Pedagogy in the world today: An analysis of the academic, training and professional perspectives. Br. J. Soc. Work. 2020, 50, 701-721. [CrossRef]

9. Basic, G.; Matsuda, Y. Inclusion and obstacles in the Swedish social pedagogical context: An analysis of narratives on working with unaccompanied refugee minors with wartime experiences in institutional care. Croat. Rev. Rehabil. Res. 2020, 56, 1-18. [CrossRef]

10. Úcar, X.; Soler-Masó, P.; Planas-Lladó, A. Working with Young People: A Social Pedagogy Perspective from Europe and Latin America; Oxford University Press Inc.: Oxford, UK, 2020.

11. Lokareva, G.V. Art-Aesthetic Information as a Pedagogical Problem: Monograph; Zaporizhzhia National University: Zaporizhzhia, Ukraine, 2001.

12. Bekker, Y.; Zhuravchik, V. Educational space as a social and pedagogical category. Izvestiya. Penza State Pedagog. Univ. Named After, V. Belinsky 2009, 12, 132-140.

13. Tsymbalaru, A. Component-structural analysis of the concept of "educational space". In Annotated Results of the Research Work of the Institute of Pedagogy; Pedahohichna Dumka: Kyiv, Ukraine, 2008.

14. Kryvykh, S. Correlation of the concepts of "environment" and "space" in the socio-cultural and educational aspects. Izvestiya. Altai State Univ. 2010, 21, 14-18.

15. Björkenstam, C.; Ringbäck Weitoft, G.; Hjern, A.; Nordström, P.; Hallqvist, J.; Ljung, R. School grades, parental education and suicide-A national register-based cohort study. J. Epidemiol. Community Health 2011, 65, 993-998. [CrossRef]

16. Bäckman, O.; Estrada, F.; Nilsson, A.; Shannon, D. The Life Course of Young Male and Female Offenders: Stability or Change Between Different Birth Cohorts? Br. J. Criminol. 2014, 54, 393-410. [CrossRef]

17. Gauffin, K.; Vinnerljung, B.; Fridell, M.; Hesse, M.; Hjern, A. Childhood socio-economic status, school failure and drug abuse: A Swedish national cohort study. Addiction 2013, 108, 1441-1449. [CrossRef] [PubMed]

18. Engdahl, M.; Forslund, A. En Förlorad Generation? Om Ungas Etablering på Arbetsmarknaden (A Lost Generation? On the Establishment of Youth in the Labour Market); The Institute for Evaluation of Labour Market and Education Policy: Uppsala, Sweden, 2016. 
19. Fuller, K. New Lands, New Languages: Navigating Intersectionality in School Leadership. Front. Educ. 2018, 3. [CrossRef]

20. Lokareva, G.V. The Functional Capabilities of Artistic and Aesthetic Information in Work of Art. In Professional Artistic Education and Culture within Modern Global Transformations; Olga Oleksiuk, O., Ed.; Cambridge Scholars Publishing: Newcastle upon Tyne, UK, 2018; pp. 85-91.

21. Lokareva, G.; Gualotunya, R. Music Therapy as a Social and Pedagogical Technology. Bull. Zap. Natl. Univ. Pedagog. Sci. 2019, 1, 29-33.

22. Lokareva, G.V.; Stadnichenko, N.V. Pidhotovka Majbutn'oho Aktora do Profesijnoho Spilkuvannja: Teoretyčnyj ta Praktyczne Aspekty: Monografija; Zaporizhzhia National University: Zaporizhzhia, Ukraine, 2019.

23. Warne, M.; Svensson, Å.; Tirén, L.; Wall, E. On Time. A Qualitative Study of Swedish Students', Parents' and Teachers' Views on School Attendance, with a Focus on Tardiness. Int. J. Environ. Res. Public Health 2020, 17, 1430. [CrossRef] [PubMed]

24. Medegård, E.; Henrixon, K.; Basic, G. Successes and obstacles in the work of upper-secondary schools with newly arrived students: a constructivist-inspired analysis of teachers' verbal accounts regarding their schools' organizational and practical work, submitted.

25. Greve, R.; Andersson, C.; Basic, G. Interactive advantage, cementing of positions, and social pedagogical recognition-A narratively inspired analysis of professional actors' oral representations of health promotion, prevention, and remediation efforts. submitted.

26. Hjern, A.; Arat, A.; Vinnerljung, B. Att Växa upp Med Föräldrar som har Missbruksproblem eller Psykisk Sjukdom-Hur ser Livet ut $i$ ung Vuxen Ålder? (Growing Up with Parents Who Have Substance Abuse Problems or Psychiatric Illness-What Is Life Like for Young Adults?); The Swedish Family Care Competence Centre: Stockholm, Sweden, 2014.

27. Vinnerljung, B.; Andreassen, T. Barn och Unga i Samhällets Vård. Forskning om den Sociala Dygnsvården. (Children and Young People in Social Care. Research on Foster Care and Institutional Care); Forte: Stockholm, Sweden, 2015.

28. Foster, R. The Pedagogy of Recognition. Dancing Identity and Mutuality. Dissertation in Education Thesis, University of Tampere, Tampere, Finland, 2012.

29. Björk, K.; Danielsson, E.; Basic, G. Collaboration and identity work: A linguistic discourse analysis of immigrant students' presentations concerning different teachers' roles in a school context. Rev. Educ. Pedagog. Cult. Stud. 2019, 41, 26-47. [CrossRef]

30. Johnsson, A.; Blivik, G.; Basic, G. Newly arrived parents and collaboration in Swedish school context: An interactionally and ethnomethodologically inspired analysis. Education 2021, 141, 127-144. Available online: http://lnu.diva-portal.org/smash/record. jsf?faces-redirect=true\&aq2=\%5B $\% 5 B \% 5 \mathrm{D} \% 5 \mathrm{D} \& \mathrm{af}=\% 5 \mathrm{~B} \% 5 \mathrm{D} \&$ searchType=SIMPLE\&sortOrder2=title_sort_asc\&language= en\&pid=diva2\%3A1541798\&aq=\%5B\%5B\%5D \%5D\&sf=all\&aqe=\%5B \%5D\&sortOrder=author_sort_asc\&onlyFullText=false\& noOfRows $=50 \& d s w i d=822$ (accessed on 12 August 2021).

31. Fothergill, K.E.; Ensminger, M.E. Childhood and adolescent antecedents of drug and alcohol problems: A longitudinal study. Drug Alcohol Depend. 2006, 82, 61-76. [CrossRef]

32. Trenz, R.C.; Dunne, E.M.; Zur, J.; Latimer, W.W. An investigation of school-related variables as risk and protective factors associated with problematic substance use among vulnerable urban adolescents. Vulnerable Child. Youth Stud. 2015, 10, 131-140. [CrossRef]

33. Sikorska, L. Formation of Communicative Skills of Future Managers in the Process of Learning Foreign Languages. Ph.D. Thesis, (Pedagogic). Institute Education of the Academy of Pedagogical Sciences of Ukraine, Kyiv, Ukraine, 2005.

34. Amelina, S. Theoretical and Methodical Bases of Formation of Culture of Professional Communication of Students of Higher Agrarian Educational Institutions. Ph.D. Thesis, Kharkiv National Pedagogical University, Kharkiv, Ukraine, 2008.

35. Bychok, A. Formation of Culture of Professional Communication of Future Specialists of International Business and Management. Ph.D. Thesis, Ternopil National Pedagogical University, Ternopil, Ukraine, 2010.

36. Litvinova, O. Formation of Culture of Professional Communication in Future Specialists of Agrarian Profile. Ph.D. Thesis, (Pedagogic). Classic Private University, Zaporizhzhya, Ukraine, 2012.

37. Linnaeus University. Project: School Success for Newly Arrived Students: Possibilities, Obstacles, Identities and Collaboration. Available online: https://lnu.se/en/research/searchresearch/forskningsprojekt/project-school-success-for-newly-arrivedstudents/ (accessed on 12 August 2021).

38. Linnaeus University. Project: School as a Protection Factor. An Analysis of Achievements, Obstacles, Collaboration, and Identities in Senior High School Work with Students Who Use Alcohol and Drugs. Available online: https://lnu.se/en/research/ searchresearch/forskningsprojekt/project-school-as-a-protection-factor/ (accessed on 12 August 2021).

39. Larochelle, M.; Bednarz, N.; Garrison, J. Constructivism and Education; Cambridge University Press: Cambridge, UK, 1998.

40. Taber, K. Constructivism as educational theory: Contingency in learning, and optimally guided instruction. In Educational Theory; Hassaskhah, J., Ed.; 2011; pp. 39-61.

41. Bateman, A. Conversation Analysis and Early Childhood Education. The co-production of knowledge and relationships. In Book Series: Directions in Ethnomethodology and Conversation Analysis; Routledge: London, UK, 2018.

42. Farr, F.; Farrell, A.; Riordan, E. Social interaction in language teacher education. A corpus and discourse perspective. In Book Series: Studies in Social Interaction; Edinburgh University Press: Edinburgh, UK, 2019.

43. Deevia, B.; Singh, S.; Thabo, M. Gender, sexuality and violence in south african educational spaces. In Book Series: Palgrave Studies in Gender and Education; Springer: Berlin/Heidelberg, Germany, 2021. 
44. Krompák, E.; Fernández-Mallat, V.; Stephan, M. Linguistic landscapes and educational spaces. In Book Series: New Perspectives on Language and Education; Multilingual Matters: Bristol, UK, 2021.

45. Berger, P.L.; Luckmann, T. The Social Construction of Reality. A Treatise in the Sociology of Knowledge; Anchor Books: New York, NY, USA, 1966.

46. Garfinkel, H. Studies in Ethnomethodology; Prentice Hall: New York, NY, USA, 1984

47. Blumer, H. Symbolic Interactionism. Perspective and Method; University of California Press: Los Angeles, CA, USA, 1986.

48. Gubrium, F.J.; Holstein, A.J. The New Language of Qualitative Method; Oxford University Press: New York, NY, USA, 1997.

49. Goffman, E. The Presentation of Self in Everyday Life; Penguin Books: London, UK, 2002.

50. Collins, R. Interaction Ritual Chains; University Press: Princeton, UK, 2004.

51. Mead, G.H. Mind, Self and Society; University of Chicago Press: Chicago, IL, USA, 2015.

52. Burr, V. Social Constructionism; Routledge: New York, NY, USA, 2015.

53. Basic, G. When Collaboration Becomes a Struggle. A Sociological Analysis of a Project in the Swedish Juvenile Car. Dissertation in Sociology, Lund University, Lund, Sweden, 2012.

54. Silverman, D. Qualitative Research. Theory, Method and Practice; Sage: London, UK, 2006.

55. Hammersley, M.; Atkinson, P. Ethnography: Principles in Practice; Routledge: London, UK, 2007.

56. Riessman, C.K. Narrative Methods for the Human Sciences; Sage: Thousand Oaks, CA, USA, 2008.

57. Silverman, D. Interpreting Qualitative Data; Sage: London, UK, 2015.

58. Wästerfors, D.; Åkerström, M.; Jacobsson, K. Reanalysis of qualitative data. In The SAGE Handbook of Qualitative Data Analysis; Flick, U., Ed.; Sage: London, UK, 2013; pp. 467-480.

59. Chumychova, R.; Redko, L. Theoretical Approaches and Design of Education in Modern Conditions; YRO: Stavropol, Russia, 1996.

60. Pogrebova, N. The educational space of the lyceum as a condition for the development of the research function of a teacher. In Candidate of Pedagogical Sciences Dissertation; Stavropol State Pedagogical Institute: Stavropol, Russia, 2006.

61. Leonova, O. Educational space as a pedagogical reality. Alma Mater. Bull. High. Educ. 2006, 1, 36-40.

62. Koning, I.M.; van den Eijnden, R.J.J.M.; Engels, R.C.M.E.; Verdurmen, J.E.E.; Vollebergh, W.A.M. Why target early adolescents and parents in alcohol prevention? The mediating effects of self-control, rules and attitudes about alcohol use. Soc. Study Addict. 2010, 106, 538-546. [CrossRef]

63. Sznitman, S.R.; Dunlop, S.M.; Nalkur, P.; Khurana, A.; Romer, D. Student Drug Testing in the Context of Positive and Negative School Climates: Results from a National Survey. J. Youth Adolesc. 2012, 41, 146-155. [CrossRef]

64. Popov, O.; Sturesson, E. Facing the pedagogical challenges of teaching unaccompanied refugee children in the Swedish school system. Probl. Educ. 21st Century 2015, 64, 66-74. [CrossRef]

65. Onrust, S.A.; Otten, R.; Lammers, J.; Smit, F. School-based programmes to reduce and prevent substance use in different age groups: What works for whom? Systematic review and meta-regression analysis. Clin. Psychol. Rev. 2015, 44, 45-59. [CrossRef]

66. Torbjørnsen, H.L. They don't know what it means to be a student: Inclusion and exclusion in the nexus between 'global' and 'local'. Policy Futures Educ. 2016, 14, 666-686.

67. Wedin, Å. Arbete med identitetstexter. Flerspråkigt skrivande för identitetsförhandling och engagemang. Nord. Nord. Tidsskr. 2017, 1, 45-61.

68. Eek-Karlsson, L.; Lundin, M.; Torpsten, A.-C. Likabehandlingsarbete-en reproduktion av rådande maktordning? Educ. Vetensk. Skr. 2020, 2, 49-73. [CrossRef]

69. Berggren, J.; Torpsten, A.-C.; Järkestig Bergren, U. Education is my passport: Experiences of institutional obstacles among immigrant youth in the Swedish upper secondary educational system. J. Youth Stud. 2020, 24, 340-354. [CrossRef]

70. Medegård, E.; Henrixon, K. Framgångar, Hinder och Samverkan i Arbetet med Nyanlända Elever. En Socialkonstruktivistisk Analys av Specialpedagogers Berättelser (Successes, Obstacles and Collaboration in Work with Newly Arrived Students. A Social Constructivist Analysis of Special Educators Narratives). Växjö and Kalmar: Linnaeus University. Independent Work in the Special Pedagogy (Second Cycle). 2020. Available online: https:/ /www.diva-portal.org/smash/get/diva2:1473785/FULLTEXT0 1.pdf (accessed on 12 August 2021)

71. Andersson, C.; Greve, R. Framgångar och Hinder i Gymnasieskolans Arbete med Elever som Använder Alkohol och Narkotika. En Interaktionistisk Analys av Verbala Framställningar om Skolans Organisatoriska och Praktiska Arbete (Achievements and Obstacles in Senior High School Work with Students Who Use Alcohol and Substances. An Interactional Analysis of Verbal Descriptions Con-Cerning Organisational and Practical Work in School). Växjö and Kalmar: Linnaeus University. Independent Work in the Special Pedagogy (Second Cycle). 2020. Available online: http://lnu.diva-portal.org/smash/get/diva2: 1484216/FULLTEXT01.pdf (accessed on 12 August 2021).

72. Bhopal, K.; Preston, J. (Eds.) Intersectionality and Race in Education, 1st ed.; Routledge: London, UK, 2011.

73. Basic, G. Ethnic monitoring and social control: Descriptions from juveniles in juvenile care institutions. Nord. Soc. Work Res. 2015, 5, 20-34. [CrossRef] 